\title{
The strategy of shifting cultivators in West Kalimantan in adapting to the market economy: empirical evidence behind gaps in interdisciplinary communication
}

\author{
Prudensius Maring ${ }^{1}$ \\ Budi Luhur University, Indonesia
}

\begin{abstract}
Issues of climate change and expansion of large-scale land acquisition for industrial plantations continue to ravage the shifting cultivation system that 300-500 million subsistence farmer households depend on. In Indonesia, particularly in Kalimantan and Sumatera, village communities continue to practice shifting cultivation amidst the conversion of lands into industrial plantations. The rampant conversion of farmer's land by large scale companies based in the market economy has resulted in the decline of the shifting cultivation system, and compelled them to enter commercial production. I employed qualitative methods, conducting indepth interviews and observations in West Kalimantan in 2018. Shifting cultivation today is not just for subsistence, but it is also a strategy to maintain claims to land that has been handed over to companies. Concurrently, people have been developing community plantations using industrial commodities such as rubber and oil palm, which still incorporate subsistence features. The changes occurring in villages have led to conflict since land availability has reduced, while the alternative of working for forestry and plantation companies is hampered by their lack of skills and knowledge. Theoretically, this study indicates the need for communication and synergy between the perspectives of political ecology and cultural ecology in order to understand the socio-politico-economic complexities haunting the village community's alterations in subsistence strategies. The practical implications are that land-based village development should open up communication among stakeholders and position village communities as the key beneficiary in the long run.
\end{abstract}

Keywords: Shifting cultivation, land conversion, adaptation strategy, market economy, political ecology, Kalimantan, Indonesia

\section{Résumé}

Les problèmes du changement climatique et de l'expansion de l'acquisition de terres à grande échelle pour les plantations industrielles continuent de ravager le système de culture itinérante dont dépendent 300 à 500 millions de ménages d'agriculteurs de subsistance. En Indonésie, en particulier à Kalimantan et à Sumatera, les communautés villageoises continuent de pratiquer la culture itinérante au milieu de la conversion des terres en plantations industrielles. La conversion effrénée des terres des agriculteurs par de grandes entreprises basées dans l'économie de marché a entraîné le déclin du système de culture itinérante et les a obligés à entrer dans la production commerciale. J'ai utilisé des méthodes qualitatives, mené des entretiens et des observations approfondis dans le Kalimantan occidental en 2018. J'ai constaté qu'aujourd'hui, la culture itinérante n'est pas seulement pour la subsistance, mais c'est aussi une stratégie pour maintenir la revendication des terres qui ont été cédées aux entreprises. Parallèlement, la population locale a développé des plantations communautaires utilisant des produits industriels tels que l'hévéa et le palmier à huile, qui incorporent encore des caractéristiques de subsistance. Les changements qui se produisent dans les villages ont conduit à des conflits depuis que la disponibilité des terres a été réduite, tandis que l'alternative de travailler pour les entreprises forestières et de

\footnotetext{
${ }^{1}$ Dr. Prudensius Maring, Associate Professor and lecturer in the Faculty of Communication Science, Budi Luhur University, Jakarta, Indonesia. My research concerns cultural anthropology, ecological anthropology, political ecology, and cultural communication. Email: prudensius.maring "at" budiluhur.ac.id. I would like to convey my gratitude for the support given in my writing this article: Dr. Wendi Usino as the Rector of Budi Luhur University; Dr. Nawiroh Vera as the Dean of the Faculty of Communication Science; Dr. Krisna Adiyarta as the Director of Research and Community Service; Professor Dr. Iswandi Syahputra who reviewed the draft of the article; and Dr. Umaimah, my fellow faculty member. I would also like to thank Agung Nugraha and Junaidi Maksum, fellow researchers from Wana Aksara Institute for their support. I would also like to convey my appreciation to the two anonymous reviewers who provided extensive comments.
} 
plantation est entravée par leur manque de compétences et de connaissances. Théoriquement, cette étude indique le besoin de communication et de synergie entre les perspectives de l'écologie politique et de l'écologie culturelle, afin de comprendre les complexités socio-politico-économiques qui hantent les changements de la communauté villageoise dans les stratégies de subsistance. Les implications pratiques sont que le développement villageois basé sur la terre devrait ouvrir la communication entre les parties prenantes et positionner les communautés villageoises comme les principaux bénéficiaires à long terme.

Mots clés: Culture itinérante, conversion des terres, stratégie d'adaptation, économie de marché, écologie politique, Kalimantan, Indonésie

\section{Resumen}

El cambio climático y la expansión de compra de tierras a gran escala para plantaciones industriales, sigue devastando el sistema de rotación de cultivos del que dependen entre 300 y 500 millones de familias campesinas. En Indonesia, particularmente en Kalimantan y Sumatra, comunidades rurales siguen practicando la rotación de cultivos en medio de la transformación de tierras a plantaciones industriales. La transformación desenfrenada de tierras campesinas por parte de grandes compañías basadas en la economía de mercado, ha resultado en el declive del sistema de rotación de cultivos y ha impulsado a los agricultores a incorporarse a la producción comercial. Para el análisis, utilicé métodos cualitativos, realicé entrevistas a profundidad y llevé a cabo observaciones en el oeste de Kalimantan, en 2018. Actualmente, la rotación de cultivos no se utiliza únicamente para la subsistencia, sino también es una estrategia para mantener el derecho de la tierra que ha sido transferida a empresas. Simultáneamente, la población ha desarrollado plantaciones comunales utilizando mercancías industriales tales como caucho y aceite de palma, las cuales integran funciones de subsistencia. Los cambios ocurridos en las poblaciones han derivado en conflictos ya que la disponibilidad de tierras se ha reducido, mientras que la opción de trabajar en silvicultura y para empresas de plantación se ve obstaculizada por la falta de habilidades y conocimiento. Teóricamente, este estudio apunta a la necesidad de una comunicación y sinergia entre las perspectivas de ecología política y ecología cultural para entender las complejidades socio-políticas y económicas que persisten en las alteraciones de las estrategias de subsistencia de las comunidades. Las implicaciones prácticas se encuentran en que el desarrollo comunitario basado en la tierra debe facilitar la comunicación entre los involucrados y colocar a las comunidades como las beneficiarias claves a largo plazo.

Palabras clave: rotación de cultivos, transformación de suelos, estrategia de adaptación, economía de mercado, ecología política, Kalimantan, Indonesia

\section{Introduction}

Shifting cultivation in the tropics is challenged by environmental conservation interests, pressures to secure livelihood, and economic investment through the expansion of large-scale industrial plantations (Li et al. 2014). Arguments representing the interests of environmental conservation disapprove of shifting cultivation since these agricultural practices are considered a precursor to land degradation and forest fires. Opposition is further translated into policies and regulations restricting and prohibiting slash and burn activities (Thung 2018). The arguments for farmers' socio-economic interests support shifting cultivation, since it is seen as a basis for local people to make ends meet (as a source of livelihood) while protecting communities from economic fluctuations that are beyond the control of farmers. Communities maintain local wisdom and technology that can prevent land and forest fires (Dove 2015; Li et al. 2014). Despite these disagreements, shifting cultivation is facing significant challenges from external economic and political pressures, with the conversion of land into large scale industrial plantations areas for forestry and plantation crops (Li 2015, 2016; Toumbourou and Dressler 2020).

This is the context for shifting cultivation in Indonesia, continuing amid conflictual and powerful interests (Meilasari-Sugiana 2018). Rural communities in Kalimantan have conducted shifting cultivation over generations, to meet their subsistence needs (Dove 2015; Siahaya et al. 2016; Thung 2018). Villagers in East Kalimantan continue to engage in the practice despite the government prohibiting forest and agricultural burning (Li et al. 2014; Thaler and Anandi 2017; Thung 2018). This is also the case in West Kalimantan. Some land acquisition for oil palm plantations has been obstructed by the maintenance of shifting cultivation (Vos 2013). In regions of Aceh and other parts of Sumatera, villagers clash with conservation campaign programs 
calling upon the community to abandon shifting cultivation (McCarthy 2010; Setyowati 2020). Shifting cultivators face changing strategies and choices given the social economic rationalities they encounter.

In sum, global environmental conservation and political economic pressures clash with the practice of smallholder agriculture in Indonesia, whose government has responded to both interests. Concerns over climate change and the global REDD agenda (Reducing Emissions from Deforestation and Forest Degradation) have, over the last three decades, targeted the practice of shifting cultivation (Chan and Takeda 2016; Li and Feng 2016; Li et al. 2014; Setyowati 2020; Terauchi et al. 2014). Shifting cultivation is considered one of the precursors to carbon emissions, and a contributor to them. In Indonesia, for instance, shifting cultivation is thwarted by regulations prohibiting burning, although land clearing by fire is also carried out by large scale forestry and plantation companies nearby (Thung 2018). Shifting cultivators are nonetheless accused of burning forest land (Dressler et al. 2017).

The Law on Foreign Investment in 1967 and the Law on Domestic Investment in 1968 were an early clash between the traditional economic system and the large scale commercial exploitation of natural resources (Minardi and Maulani 2019). ${ }^{2}$ The politico-economic implications are apparent in the government's land allocation policy and attitude towards communities. State forest areas categorized as production forest or with other land uses (outside of the forest area) are allocated to companies engaged in extensive scale plantations and forestry (industrial forest plantations). In the oil palm plantation sector, for instance, in 2015 a land area of 11.4 million hectares had been utilized to achieve export of 33 million tons of crude palm oil (CPO) with revenue amounting to US\$20.75 billion. The Government of Indonesia planned to allocate 10.15 million hectares of production forest for non-forestry use out of the total 68.99 million hectares (Palupi et al. 2017).

In contrast, community land use for livelihoods and farming is considered slow, small-scale, and a hindrance to large scale investments. Communities are considered to lack the capacity to manage large scale forestry and plantation businesses (Bissonnette and Koninck 2015; Li et al. 2014). Meanwhile, the presence of oil palm plantations in Kalimantan for instance, which are supported by a product manufacturing industry, has actually caused social-economic problems locally by disrupting livelihood opportunities, by not addressing labor injustices, and leading to violence against Indigenous communities (Petrenko et al. 2016; Sirait 2009; Vos 2013).

The presence of large-scale commercial entities has an impact in changing the subsistence strategy employed by shifting cultivators in the villages. Aside from continuing to carry out small scale agriculture, some people have shifted their source of livelihood to the community plantation model on company lands, where large concessions have been granted. Another alternative strategy is for farmers to become employees with one of the new forestry and plantation companies located around their village. The description above demonstrates the complexity of issues confronted by shifting cultivators living contiguously to forest lands in rural, mountainous, and upland areas. The research question here is, amidst such complexity, what strategy do shifting cultivators use to adapt to the pressures of the market economy?

\section{Shifting cultivation, changes in ecology and economy}

As mentioned by Li et al. (2014), the shifting cultivation system has experienced change from being oriented toward fulfilling subsistence needs to domination by market-oriented land uses (Li et al. 2014; Thaler and Anandi 2017). However, data is lacking or uncertain on the geographical extent of shifting cultivation land area, the demographics of affected rural areas, and biophysical and socio-economic impacts. The number and distribution of villagers who depend on shifting cultivation, and their wellbeing, is not clearly known (Li et al. 2014).

Opponents of shifting cultivation see it as destructive and unsustainable, making it a necessity to find alternative agricultural models. A key phase in shifting cultivation considered incapable of promoting sustainability is the conversion phase, involving the clearing of forest land for agriculture. This is then followed by the planting stage for 1-2 years, and fallowing to recover land fertility and vegetation cover. The fallow land

\footnotetext{
${ }^{2}$ Such rules have become reinforced, as observed in the implementation of Law No. 11/2020 on Job Creation, which mainly aims to boost investment by lessening land acquisition and business permit requirements.
} 
period, as the key to restoring vegetation, generally shortens as a result of population growth, market pressure, and conservation policies. Proponents of shifting cultivation consider it the most dominant system of land use in Southeast Asia that can guarantee food subsistence needs and anticipate fluctuations in commodity prices at the market level. Although policies have restricted shifting cultivation and provided opportunities for large scale economic investments, it has persisted (Dove 2015; Li et al. 2014; Mertz and Bruun 2017; Rahman et al. 2017; Siahaya et al. 2016; Thung 2018).

There is an ambivalence about the role of farmers faced with land use pressures from conservation and economic investment interests. First, in the case of natural resources (land and forest) acquisition more generally, it is commonplace for the government to position farmers as encroachers on forest and land (Peluso 1992). Second, this is similarly observed in the case of shifting cultivation. Groups that oppose it position farmers residing in forest fringes and in highlands as perpetrators of land-forest burning, and they are made into scapegoats ( $\mathrm{Li}$ et al. 2014; Thaler and Anandi 2017; Thung 2018). Third, proponents of shifting cultivation position farmers and shifting cultivators as followers of a sagacious subsistence system, so there is a need to defend their interest (Dove 2015; Thaler and Anandi 2017). Supporters place shifting cultivation as a strategy to meet the subsistence needs of farmers and ecological processes. This group criticizes policies that force the transition of land use from shifting cultivation toward intensive planting and management, deeming them to be misguided (Dressler et al. 2017). Change in land use towards intensive annual cropping indicates an increase in household income, but there are reductions in customary practices, socio-economic welfare, and livelihood options. Intensification is considered to have lowered the security of farmer's livelihood and lessened ecosystem services. The direction suggested by proponents is to conduct land management together with shifting cultivators and farmers, regulating fallowing to support cultivation (of food crops and annual crops) while maintaining ecological function (Dressler et al. 2017; Rahman et al. 2017). Fourth, in the context of economic investment interests, shifting cultivators and farmers in villages are always concurrently positioned as objects of land acquisition and as subjects that are lured into becoming company employees (Li 2015, 2016; Setyowati 2020).

Behind the negative labelling ascribed to the shifting cultivators/farmers, the livelihood strategies they employ in the forest fringes and highlands continue to alter in response to the market economy (Thaler and Anandi 2017). Subsistence and resistance strategies, as a part of the farmers' subculture, are no longer observed in isolation but in response to the dynamics of socioeconomic change and political authority unfolding around them, which affects their livelihood activities (Abu-Lughod 1990; Maring 2015; Scott 1976, 1985). This has occurred over the last three decades, supplemented by technological and cultural shifts, population growth and labor dynamics (Dove 2015; Li 2015; Li et al. 2014; Thaler and Anandi 2017). Shifting cultivation is not only a subsistence strategy to meet the farmer's source of livelihood, but it is also a political and economic strategy (Thaler and Anandi 2017). Indeed, farmers in East Kalimantan implement shifting cultivation as a political strategy to acquire and secure their land and natural resources. At the district and village levels, land conversion for plantations and mining needs to be controlled (Li 2015, 2016; Thaler and Anandi 2017). People ensure their claim to land and try to fend off the expansion of plantations and mining.

Nonetheless, there is sufficient ambiguity in existing research to question the sanctity of traditional shifting cultivation, and indeed the transition to annual crop production in the South East Asian tropics is sometimes initiated by communities themselves as their local knowledge, wisdom, technologies, and socioeconomic rationalities alter over time (Choocharoen et al. 2014; Rahman et al. 2017). The process of changing the shifting cultivation system is a broad socio-economic adaptation strategy. Adaptation is apparent in terms of the alteration in farmer's choices of annual crop varieties, changes to planting periods, and amendments made to annual crop management. Attention to the level of farmer's education, experience, land holdings and ownership, access to market information, and extension services can help farmers carry out calculated adaptation to changes in their socio-economic surroundings (Abid et al. 2015; Islam and Berkes 2016; Ndamani and Watanabe 2015; Olayemi and Nirmala 2016; Sima et al. 2015).

There is a communication gap between supporters and detractors of shifting cultivation. Complexities in the differing perspectives applied to shifting cultivation can benefit from a synergy of political ecology and cultural ecology approaches. The cultural ecology perspective has contributed to the viewpoint that shifting cultivation is a material response to meeting livelihood needs, as well as the implementation of a subsistence 
economic strategy that evolves with local culture, knowledge, and technology (Dove 2015; Geertz 2016; McCullough 2019; Scott 1976). The political ecology perspective places greater attention on structural, multiscale issues including policy effects and politics, historical change, social networks and gender, injustices and vulnerability, economic-political pressures, and concerns over climate change issues (Elmhirst et al. 2017; Friedmann 2015; Li 2015; Mathevet et al. 2015; Ndamani and Watanabe 2015; Olsson and Jerneck 2010; Peluso 1992, 2005; Ring 2020; Sima et al. 2015; Thung 2018; Toumbourou and Dressler 2020; Willow and Wylie 2014; Zanotti et al. 2020; Zimmerer and Bassett 2003). A synergy of the two perspectives is crucial in order to reestablish an integrated understanding on the correlation between economic political struggle for environmental resources, the cultural meanings attached to an environment, and the changing dynamics of ecology-environment (Benjaminsen and Svarstad 2019; Nygren and Rikoon 2008; Peterson 2000; Quandt 2016).

\section{Methodology and analytical approach}

This article is based on a qualitative approach using primary data largely collected from field studies between April to August of 2018 in three villages (abbreviated to KD, PB, and SJ) in Kendawang District, Ketapang Regency, West Kalimantan Province, Indonesia (Figure 1). I conducted in-depth interviews and participatory observation (Almalki 2016; Archibald et al. 2015; Creswell 2013; Nassaji 2015). The interviews addressed practices of shifting cultivation, subsistence economic systems, and the strategy used by the community to adapt to the market economy. Observation triangulated the data acquired through interviews, which include among others data relating to tillage, crop variety, activity sites, conditions of community plantations, and shifting cultivation land areas.

There were a total of 28 informants from the three villages consisting of 9 village level government employees, 5 sub-village level community and customary figures, 13 villagers who relied on farming as their means of livelihood, and one company employee. The informants were between 35 to 50 years old with 25 men and only three women. All the informants, including village administration personnel, customary and community figures considered farming as their principal occupation. The company employee was interviewed to gain an outlook on the relationship between the community and the company, and labor issues. All respondents were fluent in Indonesian.

The communities in the three villages of study reside in and around the state forest area, which has now become a concession area for forestry companies. The population of the three villages was 2,456 (Anonymous 2017; Nugraha and Tim 2018). Most of the inhabitants in the three villages were of Dayak ethnicity, which consisted of the Dayak Siapitan, Dayak Batu Keling, and Dayak Membulu sub-ethnic groups. In addition to Dayaks, the villages were also inhabited by people of Malay ethnicity. There were also a limited number of other ethnic groups such as Javanese, Batakese, Bugis, and Flores, given Indonesia's history of transmigration programs and migration. The Dayak ethnic group reside in kampongs with ethnic symbols and kedemungan customary institutions.

These communities practice shifting cultivation, but there are three dominant agricultural systems, namely shifting cultivation implemented by the community, community plantations in the form of rubber and oil palm, and oil palm and industrial forest plantations owned by companies. The shifting cultivation system is the village community's main source for meeting their dietary needs, aside from limited hunting, catching fresh water (river) fish, harvesting rattan, beekeeping, and maintaining swiftlet (Aerodramus fuciphagus) edible nests, sold across Asia (Connolly 2017). The communities can meet their need for cash, particularly, from community plantations and working as an employee at companies around the villages. The kampongs of the three villages of study were located in and around one company's concession area. The community's enthusiasm for exploiting oil palm and rubber plantations had strengthened since the start of the 2000s when industrial plantation companies arrived around the villages. Since 2012, communities in the three villages felt the presence of the plantation companies directly with industrial forest plantations in and around them (Nugraha and Tim 2018).

Data analysis was initially carried out by organizing field notes and classifying data into themes: shifting cultivation practices, the subsistence economic system, and community activities in adapting to the market 
economy. These data categories help to reassess data availability, sufficiency, and validity to explain what strategies are employed by shifting cultivators to adapt to economic pressures. A cultural ecology framework helps to understand the subsistence strategy that is inherent in the shifting cultivation system, which is currently undergoing changes to respond to economics of the market. Market economy pressure and its implications on shifting cultivators are subsequently understood by using the political ecology approach.

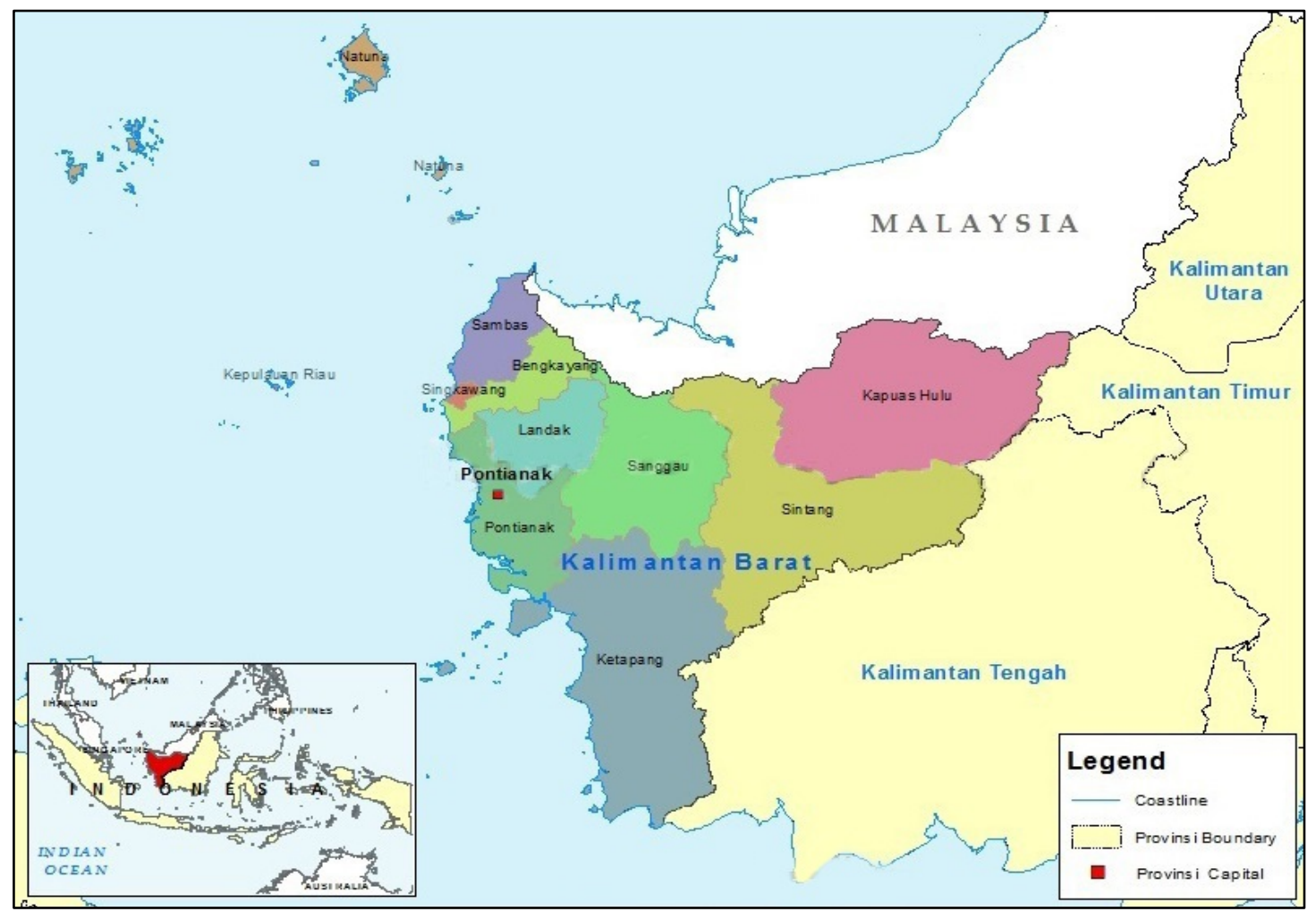

Figure 1: Research site in Ketapang, West Kalimantan (Kalimantan Barat), Indonesia. Source: http://www.indobeez.com/id/info/map/west-kalimantan.htm.

\section{Results}

\section{Shifting cultivation as a multiple strategy}

Shifting cultivation as implemented by village communities is not only a strategy to fulfill their household's dietary needs, but it is also used to acquire and maintain land. Respondents said they are currently persisting with shifting cultivation tenaciously, albeit under difficult circumstances. This is due to the limited land availability, declining soil fertility, and shorter fallow rotations. In general, in the three communities, there is approximately $0.5-1$ hectares per household. Soil fertility is declining, making it difficult to plant anything other than rice (Oryza sativa L.) within a single period of land clearing. Rotation of fallow land is shorter, now around 5-10 years. CGPRT crops (coarse grains, pulses, roots and tubers) and vegetables are only cultivated once, and after harvest the land is left to regrow as shrubs and then secondary forest. The community can no longer rely on cultivation as the only food source to provide for households.

Communities in the three villages began to experience these conditions in the early 2000s, and since 2012 industrial forest plantations and plantation companies began to appear in the region. This has happened 
across Indonesia, and elsewhere in Kalimantan, with a net lessening of land availability for shifting cultivation (Bissonnette and Koninck 2015; Terauchi et al. 2014; Vos 2013). The communities in all the villages had experienced large scale land acquisition. Shifting cultivation activities could still be observed throughout all the kampongs but plots were small, and only a few households worked them. Commonly found were rice, tubers, pineapples, bananas, and vegetables for subsistence. After a year, this was usually followed up by planting rubber. Since 2016, the lack of land had become more profoundly felt by the communities due to the ongoing processes of land acquisition and handover of land between community members and industrial forest plantation companies located around the villages. Moreover, communities had also become more cautious in cultivating because of the enforcement of governmental regulations on forest burning and the land clearing process.

The sources of land for shifting cultivation are mostly located in state forest zones, and on the small portion still formally owned by residents. However, state forest zones (production forest) around the villages have been converted into areas for industrial forest plantation (hutan tanaman industri - HTI) by granting concession rights to companies. Meanwhile, land areas formerly owned by residents outside the forest areas have mostly been converted into company-owned large-scale oil palm plantations. The community's land now lies within corporate concessions. I calculated that villagers were practicing shifting cultivation on about 1,458 hectares of corporate concessions out of the company's total area of approximately 97,891 hectares. Meanwhile, the government and different corporate players, are of the view that communities cultivating on company-owned concession land do so illegally. ${ }^{3}$ Conflict may ensue, as elaborated by other study showing cultivation in concession areas is driven not only by food needs, but also resistance to further land acquisition (Meilasari-Sugiana 2018; Nugraha and Tim 2018; Sirait 2009; Vos 2013).

The lack of land for shifting cultivation is noted across West Kalimantan. According to an informant, after securing a permit from the government in 2012, an oil palm corporation started land acquisition negotiations. It was clear to them that state forest zones were already farmed, harvested for rubber, and used for hunting. The company implemented ganti rugi tanam tumbuh - GRTT (land compensation for planting growth) in accordance with formal regulations ${ }^{4}$ and customary mechanisms. Local community figures became part of a team to speed up the land acquisition process. The land acquisition process was critical in negotiations which also promised local jobs on the plantation, even before deals were finalized. However, once land had been acquired, communities had to abide by company rules and regulations. Working relations were later severed and promises of jobs dried up: by 2018 all that remained was freelance laboring with a daily wage of IDR 70,000 - 75,000 per person per day (US\$5-5.30).

An informant explained that the company's recent unilateral termination of employment possibilities has haunted the communities. In 2018 some 452 residents of the three villages were employed by the industrial forest plantation company around the villages, in limited numbers, Some of the residents were also employed in mining which were far from the village. In 2018, there was a protest by residents of a sub-village within village $\mathrm{PB}$, when the company unilaterally terminated their employment. This sub-village is located within an industrial forest plantation. Around $90 \%$ of the residents worked at the company because ever since its arrival their lands had been lost, with compensation of only IDR 600,000 per hectare (US\$42). Forest burning was henceforth prohibited. Most of the residents worked as freelance daily labor, and only a few became permanent employees. In 2018, there were 17 plantation foremen, who had all worked since 2012, but they were demoted to daily laborers. The people of AK sub-village protested. This case was taken seriously by the community because the position of foreman is seen as an opportunity that is difficult to get for villagers who in fact only work as daily laborers because they are unable to compete with workers from outside the village. The people

\footnotetext{
${ }^{3}$ See Article 50 Verse (3) Law of the Republic of Indonesia No. 41/1999 on Forestry.

${ }^{4}$ See Regulation of the Minister of Environment and Forestry of the Republic of Indonesia: Permen-LHK RI Number: P.12/Menlhk-II/2015 on the Development of Industrial Forest Plantation.
} 
of AK sub-village protested by sending an official letter but the company did not respond, so in mid May 2018, kampong residents made a gate to obstruct entry-exit in and out of the company area.

The community's initial willingness to hand over their land for the prospect of paid labor did not fully ensure household dietary needs were met. Income from labor was not enough to substitute for food cropping. The wage for working at an industrial forest plantation company near their home was only around IDR 70,000 to IDR 75,000 per person per day (US\$5-5.30). There are prospects for higher wages, around IDR 100,000 IDR 110,000 per day (US\$7-7.80), at oil palm plantation and mining companies, which are too far from the village to return each night, resulting in higher expenditure. The socio-economic conditions faced by the community compelled them to continue practicing shifting cultivation to ensure their dietary needs. While paid labor was available, plots became smaller and more scattered further from home, and farming became a lone activity (with no working group, as was customary). Farmers said they struggled to practice local wisdom and to use their agricultural knowledge. As mentioned, plot sizes are rarely more than 0.5-1 hectares, with a land fallow period of around 5-10 years.

Technically, the tradition of shifting cultivation by planting rice and CGPRT crops is still practiced amidst the conversion of community land into industrial oil palm and forest plantations. The community still applies traditional technology in an adaptive manner, using crop selection for shifting cultivation including varieties of local rice (Oryza sativa L.), corn (Zea mays L.), tubers, and CGPRT crops. Nevertheless, given the small land parcels available, the short cultivation rotation period, and declining land productivity, it is apparent that they can no longer rely on shifting cultivation for subsistence. The communities admitted that they have to be more flexible nowadays in growing or buying food, and not all foodstuffs come from the fields. ${ }^{5}$ Work has to be taken at different types of plantations, despite the low wage rates, and the history of job losses by corporate owners. A description of shifting cultivation's political ecology-economy and technical features is provided in Table 1.

\section{Rubber plantations as a land claim and as an economic strategy}

Rubber plantations refer to the community plantation model that is extensively employed by using the natural rubber tree (Havea brasilliensis). Penot (2007) states that seedlings were initially brought from Brazil via Europe, to the botanical gardens at Buitenzorg, Java and then Kalimantan (Borneo) in 1882 under the colonial Dutch East Indies. The local governments in Kalimantan began distributing rubber plants to the community extensively in 1908. The community rubber fields (or small, mixed use community plantations) in the case study villages consist of trees growing around the villages. ${ }^{6}$ An informant said that they have long been tending to natural rubber fields, tapping the trees, and selling the latex. Informants said that rubber trees are not spaced out when planted, but incorporated into a mixed cropping model with other plants. Households in the villages usually have a rubber field of around 1-3 hectares per household. This is similar in other regions throughout Kalimantan, suggesting this mixed cropping pattern is widespread. This is done along with other activities such as farming, hunting wild animals, and scavenging non-timber forest products like rattan. According to an informant, the natural rubber they tap has good durability and a longer productive lifespan. Natural rubber trees are tapped until they are more than 35 years old, while the productive lifespan of highquality rubber variety is only 25 years. The conversion to community rubber plots usually occurs when fields are opened for cultivation, with tree planting often occurring within a year (Figures 2 and 3).

\footnotetext{
${ }^{5}$ Shifting cultivation is slowly disappearing under land pressures and corporate activities, as a form of the agricultural land extension described by Geertz (2016).

${ }^{6}$ According to the Regulation of the Minister of Forestry of the Republic of Indonesia Number: P. 35/Menhut-II/2007 on Non-Timber Forest Products, it is stated that the natural rubber tree is a non-timber forest product.
} 


\begin{tabular}{|c|c|c|}
\hline A. & \multicolumn{2}{|c|}{ Management and technical features } \\
\hline No. & Key elements & $\begin{array}{l}\text { Description } \\
\end{array}$ \\
\hline 1. & Source of land & $\begin{array}{l}\text { Land areas that are still under the control of households and those } \\
\text { that have been handed over to companies but have not been } \\
\text { cultivated. }\end{array}$ \\
\hline 2. & $\begin{array}{l}\text { Business motive and } \\
\text { character }\end{array}$ & A food subsistence strategy combined with securing land claims. \\
\hline 3. & Public enthusiasm & $\begin{array}{l}\text { Public enthusiasm for shifting cultivation ,is moderate due to lack } \\
\text { of land and low productivity. }\end{array}$ \\
\hline 4. & $\begin{array}{l}\text { Average cultivation } \\
\text { area }\end{array}$ & $\begin{array}{l}\text { Cultivation area varies with an average of } 0.5-1 \text { hectare per } \\
\text { household. }\end{array}$ \\
\hline 5. & Silviculture system & $\begin{array}{l}\text { Implementation of a cycle involving controlled slash and burn, } \\
\text { planting, and land fallowing. }\end{array}$ \\
\hline 6. & Yield/production & $\begin{array}{l}\text { Low, insufficient to meet yearly household dietary needs } \\
\text { (estimation of average rice field production in West Kalimantan is } \\
\text { approximately } 2.7 \text { tons per hectare). }\end{array}$ \\
\hline 7. & $\begin{array}{l}\text { Inception of land } \\
\text { deployed }\end{array}$ & Hereditary, with a strong tradition \\
\hline 8. & Basis of knowledge & $\begin{array}{l}\text { The community has bases of knowledge, experience, technology, } \\
\text { and wisdom. }\end{array}$ \\
\hline B. & \multicolumn{2}{|c|}{ Political ecology-economy features } \\
\hline No. & Key elements & $\begin{array}{l}\text { Description } \\
\end{array}$ \\
\hline 1. & $\begin{array}{l}\text { Solidness of business } \\
\text { at the community } \\
\text { level }\end{array}$ & $\begin{array}{l}\text { All households in the villages, be it of the dominant Dayak } \\
\text { ethnicity or of the Malay ethnicity, put in their efforts. }\end{array}$ \\
\hline 2. & $\begin{array}{l}\text { Fluctuations in sales } \\
\text { price of farmed } \\
\text { produce }\end{array}$ & Not for sale, to meet household needs for farmed produce. \\
\hline 3. & Prospect of land sales & Not for sale. \\
\hline 4. & Limiting factors & $\begin{array}{l}\text { Limited land area, declining land fertility, prohibition on forest and } \\
\text { land burning when cultivating. }\end{array}$ \\
\hline 5. & Supporting factors & Subsistence culture and local knowledge. \\
\hline 6. & $\begin{array}{l}\text { Development } \\
\text { challenges }\end{array}$ & $\begin{array}{l}\text { Large scale company land expansion through land acquisition } \\
\text { mechanisms (land conversion), large scale industrial crop expansion } \\
\text { policy (oil palm and industrial forest plantations). }\end{array}$ \\
\hline 7. & $\begin{array}{l}\text { Chain of influence } \\
\text { and actors }\end{array}$ & $\begin{array}{l}\text { Remains local, but shifting cultivation is increasingly affected by } \\
\text { company interests that are land related. }\end{array}$ \\
\hline 8. & $\begin{array}{l}\text { Future social } \\
\text { implications }\end{array}$ & $\begin{array}{l}\text { There is a narrowing of land for shifting cultivation in line with the } \\
\text { expansion of company land, so other economic livelihood activities } \\
\text { are necessary. }\end{array}$ \\
\hline
\end{tabular}

Table 1: Shifting cultivation's political ecology-economy and its technical features. Source: primary data (observations and interview results).

Respondents suggested that the use of natural rubber varieties and extensive field cultivation systems are rational choices. The extensive management system allows farmers to adapt to fluctuating market prices 
for rubber. When the price goes up, the community focuses on maintaining and tapping rubber trees that have been abandoned. Around 2010, the price of rubber had reached IDR 8,000/12,000 per kilogram (US\$0.570.85). But when the price of rubber is low, they leave their rubber field alone and concentrate on clearing land to plant rice. Harvest failure on the cultivated fields, or termination of employment by the company can drive the community to return to their rubber fields. The community rubber fields function like a buffer zone for the community. This is a strongly adaptive subsistence system, despite the fact that rubber is an industrial commodity. Other studies emphasize the significance of access to market information and support for extension or counselling services to assist farmers conduct such calculated adaptations to environmental changes (Abid et al. 2015; Ndamani and Watanabe 2015; Olayemi and Nirmala 2016; Rahman et al. 2017; Sima et al. 2015).
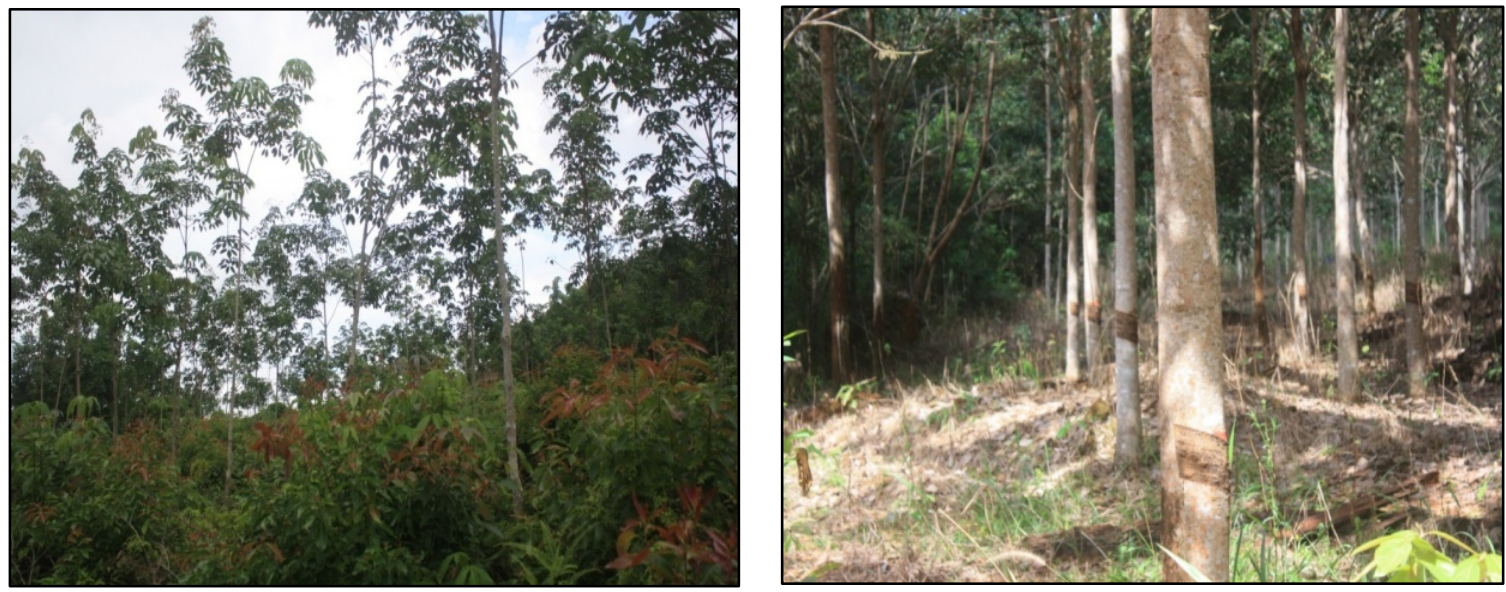

Figure 2: Community rubber trees about 2-3 years old. Figure 3: Smallholder rubber plants are mature and have been tapped. Source: Field research, May 2018.

The productivity of the rubber in Kendawang District is relatively low, with an average tapped yield of about 10-15 kilograms per hectare per day. This is due to several factors, among them the varieties cultivated, the low intensity of maintenance, and the mixed cropping model. For the last eight years, the price of rubber has been low so rubber tapping activities are less favored. In 2018, the price of rubber in the kampongs was about IDR 5,000 - IDR 6,000 per kilogram (US\$0.35-0.43), while the community considered a fair price to be about IDR 8,000 per kilogram (US\$0.57). The low price has resulted in diversification: this was elaborated by an informant as follows:

In K sub-village, rubber fields are limited, only about $40 \%$ of K sub-village residents own rubber fields. The size of their rubber field is 1 hectare per household at most. Currently the price of rubber in K sub-village is about IDR 6,000 per kilogram, so a lot of people leave their rubber fields unattended. Working on 1 hectare of rubber field does not guarantee better profit than working on a swallow nesting house with a dimension of merely 4 x 8 meter square. ${ }^{7}$

Observation and interviews indicated that the community rubber fields are located in state forest zones (the production forest) and a few are located in other land designations. The state forest zones are concession areas with management rights that have been granted to industrial forest plantation (HTI) companies. In one

\footnotetext{
${ }^{7}$ Source: Interview on May 22, 2018.
} 
60,554 hectare concession owned by an HTI company there were 88 hectares of community rubber fields. According to an informant, the rubber fields in those locations can be felled and converted to oil palm at any time. The presence of community rubber in the company's concession area indicates two things: first, the land has not been successfully acquired and put into productive use by the company; second, the community has reclaimed or is still using the land. The company has not yet planted in those locations (a statement commonly used by the company) or they have been abandoned (a statement commonly used by the community). The community's resistance to corporate land claims is expressed in maintaining their land uses regardless (Maring 2015; Nugraha and Tim 2018; Palupi et al. 2017; Vos 2013).

Multiple reasons underpin the efforts to exploit community rubber fields. Firstly, their relatively easy management. The variety of natural rubber and mixed cultivation model allows farmers the freedom to carry out other activities, like cultivation or company work. Secondly, meeting cash needs for school fees, health expenses, social costs, and purchases that are not available from the fields. Rubber helps to meet subsistence needs. Although it is included as a type of industrial commodity, the community rubber field management system still exhibits a subsistence feature that adapts to and anticipates fluctuating commodity prices. Thirdly, cultivating rubber in state forest zones is a strategy to reinforce the community's claim of land tenure over state forest zones. Fields with rubber trees as physical evidence of annual crops usually provide a higher compensation value from commercial operators, based on formal regulation and customary rules agreed upon by the implementation unit (satuan pelaksana - Satlak). ${ }^{8}$ In brief, the political ecology-economy and technical features of rubber production is provided in Table 2, and compared to oil palm.

\section{Oil palm plantations as an entry point to the market economy}

An oil palm plantation refers here to a community plantation producing an industrial commodity. An informant explained that in the last five years, people began planting oil palm trees (Elaeis oleifera) at around 1-4 hectares per household. There are even residents who exploit over 10 hectares of land. Most oil palms enter the early fruit stage by the $4^{\text {th }}$ or $5^{\text {th }}$ year. According to an informant, in a less than optimal production stage, the assumed yield for every harvest is about 200-500 kilograms per hectare. Oil palm fruit bunches are commonly harvested once every 2 weeks with the price of fresh fruit bunches at around IDR 1,000 - IDR 1,500 (US\$0.07-0.11) per kilogram at the time of the study. The community's enthusiasm for cultivating oil palm is particularly due to the ease of access to companies that purchase their yields. There are relatively few villagers living far from oil palm plantations and crude palm oil (CPO) processing plants who cultivate oil palm. Villages in the study area have easy access to trading locations, travelling around 14 kilometers. Community enthusiasm is very much determined by ease of access to price information, and sale possibilities.

Oil palm fields in the study sites are normally located in forest zones where the community has been granted permission by the company to manage them. Community oil palms are scattered around the kampongs and alongside public roads (Figure 4). Residents prefer plots situated about 250 meters alongside the company and public roads. This is permitted by the companies during the land acquisition process, as long as oil palm is grown. In fact, such promise is merely a tactic by the company to ease the process of acquiring land from the community. The community's interest in oil palm plantations is stated by an informant as follows:

Aside from working at the company, activities that SJ villagers carry out to increase their income is by cultivating oil palm trees. Around $60 \%$ of villagers have oil palm fields that they have started planting since 2015, typically they have harvested early fruits at about 60 kilograms per hectare. Oil palm field ownership in SJ village is typically around 1 hectare per household, which is usually located in the company's area and alongside public roads the company constructed. Palm tree yields are sold to the company which is about 14 kilometers away from the kampong. $^{9}$

\footnotetext{
${ }^{8}$ The implementation unit (Satuan pelaksana - Satlak) for land acquisition consists of a company representative, community figure, customary figure, and the Head of the Village.

${ }^{9}$ Source: Interview on May 24, 2018.
} 
The presence of large-scale oil palm plantations has therefore driven the community to work on palm oil fields. They are in some respects a form of collective action by communities to respond in some way to the threat of corporate land acquisition. In addition to purchasing their yields, at reliable prices, the company provides an opportunity for the community to obtain palm tree seedlings. The community communicates with employees and laborers of the oil palm plantation working in the nursery section. Residents can get free seedlings that have been discarded since they are unsuitable to plant in the company's fields (if they are on good terms with the company employee) or they can buy them cheaply. A few oil palm seedlings can also be bought from an oil palm nursery that local residents of the kampong have developed. The community's enthusiasm is in line with studies stating that the increasingly expansive and wide-spread development of company-owned oil palm plantations in various regions throughout Kalimantan has propelled the development of community oil palm fields. As I mentioned, the certainty that oil palm selling points are available is important (Santika et al. 2019; Sirait 2009). Actually, the expansion of community plantations is now progressing faster than the expansion of large scale plantations (Wibowo et al. 2019). However in the region there are 97,891 hectares of industrial concessions there are only 2,094 hectares of community oil palm plantations. ${ }^{10}$

\begin{tabular}{|c|c|c|c|}
\hline A. & \multicolumn{3}{|c|}{ Management and technical features } \\
\hline No. & Key elements & Rubber plantation & Oil palm plantation \\
\hline 1. & Source of land & $\begin{array}{l}\text { Concession land of (industrial forest } \\
\text { plantation) companies. }\end{array}$ & $\begin{array}{l}\text { Company concessions, land outside } \\
\text { of forest zones. }\end{array}$ \\
\hline 2. & $\begin{array}{l}\text { Business motive } \\
\text { and character }\end{array}$ & $\begin{array}{l}\text { Commercial, supports food } \\
\text { subsistence. }\end{array}$ & Commercial, enters market. \\
\hline 3. & $\begin{array}{l}\text { Public } \\
\text { enthusiasm }\end{array}$ & $\begin{array}{l}\text { Moderate public enthusiasm due to } \\
\text { fluctuating prices }\end{array}$ & $\begin{array}{l}\text { High public enthusiasm due to high } \\
\text { price and ease of sales. }\end{array}$ \\
\hline 4. & $\begin{array}{l}\text { Average } \\
\text { cultivation area }\end{array}$ & $\begin{array}{l}\text { Varies with an average of 1-3 } \\
\text { hectares per household. }\end{array}$ & $\begin{array}{l}\text { Varies with an average of 1-4 } \\
\text { hectares per household. }\end{array}$ \\
\hline 5. & $\begin{array}{l}\text { Silviculture } \\
\text { system }\end{array}$ & $\begin{array}{l}\text { Natural rubber, mixed crop field, } \\
\text { extensive model, flexible. }\end{array}$ & Plantations, intensive model. \\
\hline 6. & Yield/production & $\begin{array}{l}\text { Approximately 10-15 kilograms per } \\
\text { hectare per day. }\end{array}$ & $\begin{array}{l}\text { During the early fruit phase, every } \\
\text { harvest period yields about } 200 \text { - } \\
500 \text { kilograms per hectare (harvest } \\
\text { every } 14 \text { days). }\end{array}$ \\
\hline 7. & $\begin{array}{l}\text { Time of } \\
\text { inception }\end{array}$ & $\begin{array}{l}\text { Has existed together with the } \\
\text { shifting cultivation system since the } \\
\text { 1880s. }\end{array}$ & $\begin{array}{l}\text { Since the arrival of plantation } \\
\text { companies into areas around the } \\
\text { villages, over the last } 10 \text { years. }\end{array}$ \\
\hline 8. & $\begin{array}{l}\text { Basis of } \\
\text { knowledge }\end{array}$ & $\begin{array}{l}\text { The community already has } \\
\text { knowledge, experience, and skills. }\end{array}$ & $\begin{array}{l}\text { New skills, experience, and } \\
\text { knowledge. }\end{array}$ \\
\hline
\end{tabular}

\footnotetext{
${ }^{10}$ At the national level there are 14.03 million hectares of national oil palm plantation areas, and as many as 2.5 million hectares or approximately $21 \%$ of them are located in forest zones. Out of the total 2.5 million hectares of oil palm field area in the forest zones, 800,000 hectares are controlled by private plantations/SOEs while the remaining 1.7 million hectares are community plantations (Nugraha and Tim 2018; Wibowo et al. 2019).
} 


\begin{tabular}{|c|c|c|c|}
\hline B. & \multicolumn{3}{|c|}{ Political ecology-economy features } \\
\hline No. & Key elements & Rubber plantation & Oil palm plantation \\
\hline 1. & $\begin{array}{l}\text { Solidness of } \\
\text { business at the } \\
\text { community level }\end{array}$ & $\begin{array}{l}\text { Spreads evenly throughout all } \\
\text { households. }\end{array}$ & $\begin{array}{l}\text { Has not spread evenly throughout } \\
\text { all households due to lack of land } \\
\text { and capital. }\end{array}$ \\
\hline 2. & $\begin{array}{l}\text { Fluctuation of } \\
\text { selling price }\end{array}$ & $\begin{array}{l}\text { IDR } 5,000-8,000 \text { per kilogram } \\
\text { (US } \$ 0.35-0.43 \text { ) (in } 2008-2011 \text { the } \\
\text { price of rubber was around IDR } \\
10,000-12,000 \text { per kilogram). }\end{array}$ & $\begin{array}{l}\text { IDR } 1,000-1,500 \text { per kilogram } \\
\text { (one fruit bunch of mature oil palm } \\
\text { can reach an average weight of } 20- \\
35 \text { kilograms). }\end{array}$ \\
\hline 3. & Sales prospect & $\begin{array}{l}\text { Sales network is easy and available } \\
\text { in the district. }\end{array}$ & $\begin{array}{l}\text { Selling to the company is easy and } \\
\text { available. }\end{array}$ \\
\hline 4. & Limiting factors & $\begin{array}{l}\text { Limited land area, prohibition on } \\
\text { planting in industrial forest } \\
\text { plantation areas. }\end{array}$ & $\begin{array}{l}\text { Limited land area, prohibition on } \\
\text { cultivation of oil palm in state forest } \\
\text { zones, substantial business capital } \\
\text { needed. }\end{array}$ \\
\hline 5. & $\begin{array}{l}\text { Supporting } \\
\text { factors }\end{array}$ & $\begin{array}{l}\text { Easy marketing, road infrastructure } \\
\text { availability, small business capital. }\end{array}$ & $\begin{array}{l}\text { Easy marketing, many CPO } \\
\text { processing industries, road } \\
\text { infrastructure availability. }\end{array}$ \\
\hline 6. & $\begin{array}{l}\text { Development } \\
\text { challenges }\end{array}$ & $\begin{array}{l}\text { Large scale company land } \\
\text { expansion via land acquisition } \\
\text { mechanisms. }\end{array}$ & $\begin{array}{l}\text { Large scale company land } \\
\text { expansion via land acquisition } \\
\text { mechanisms. }\end{array}$ \\
\hline 7. & $\begin{array}{l}\text { Chain of } \\
\text { influence and } \\
\text { actors }\end{array}$ & $\begin{array}{l}\text { Open, influenced by the price } \\
\text { prevailing in the market and the } \\
\text { purchase of rubber products in the } \\
\text { village. }\end{array}$ & $\begin{array}{l}\text { Open, very much influenced by } \\
\text { market mechanism and company } \\
\text { interests. }\end{array}$ \\
\hline 8. & $\begin{array}{l}\text { Future social } \\
\text { implications }\end{array}$ & Potential land conflict may arise. & Potential land conflict may arise. \\
\hline
\end{tabular}

Table 2: The political ecology-economy and technical features of community rubber plantation and community oil palm plantation. Source: primary data (observation and interview results).

The description of the community rubber and oil palm plantations illustrates a form of community adaptation to a dynamic market economy. While local rubber plantations rely on sales of a product, they are still locally managed, produce natural rubber from a local variety, and provides the community with the freedom to move flexibly into market sales. When the price of rubber is high, the community focuses on their rubber fields. But when the price drops, it is possible to clear the land or cultivate oil palm instead. Rubber, today, can be introduced into the forest zone and there is a chance for a partnership between companies and local communities in accordance with the national policy for the development of industrial forests. ${ }^{11}$ While oil palm is not considered as part of the forest, it is favored by the community for the simple reason that oil palm yields are bought by the commercial operators (Wibowo et al. 2019). As a result, it is generally apparent that shifting cultivators, aside from tenaciously practicing shifting cultivation, are enthusiastic to develop small scale community plantations to adapt to the pressures imposed by the political economy of oil palm.

\footnotetext{
${ }^{11}$ See Regulation of the Minister of Environment and Forestry of the Republica of Indonesia: Permen-LHK RI Number:
} P.12/Menlhk-II/2015 on the Development of Industrial Forest Plantation. 


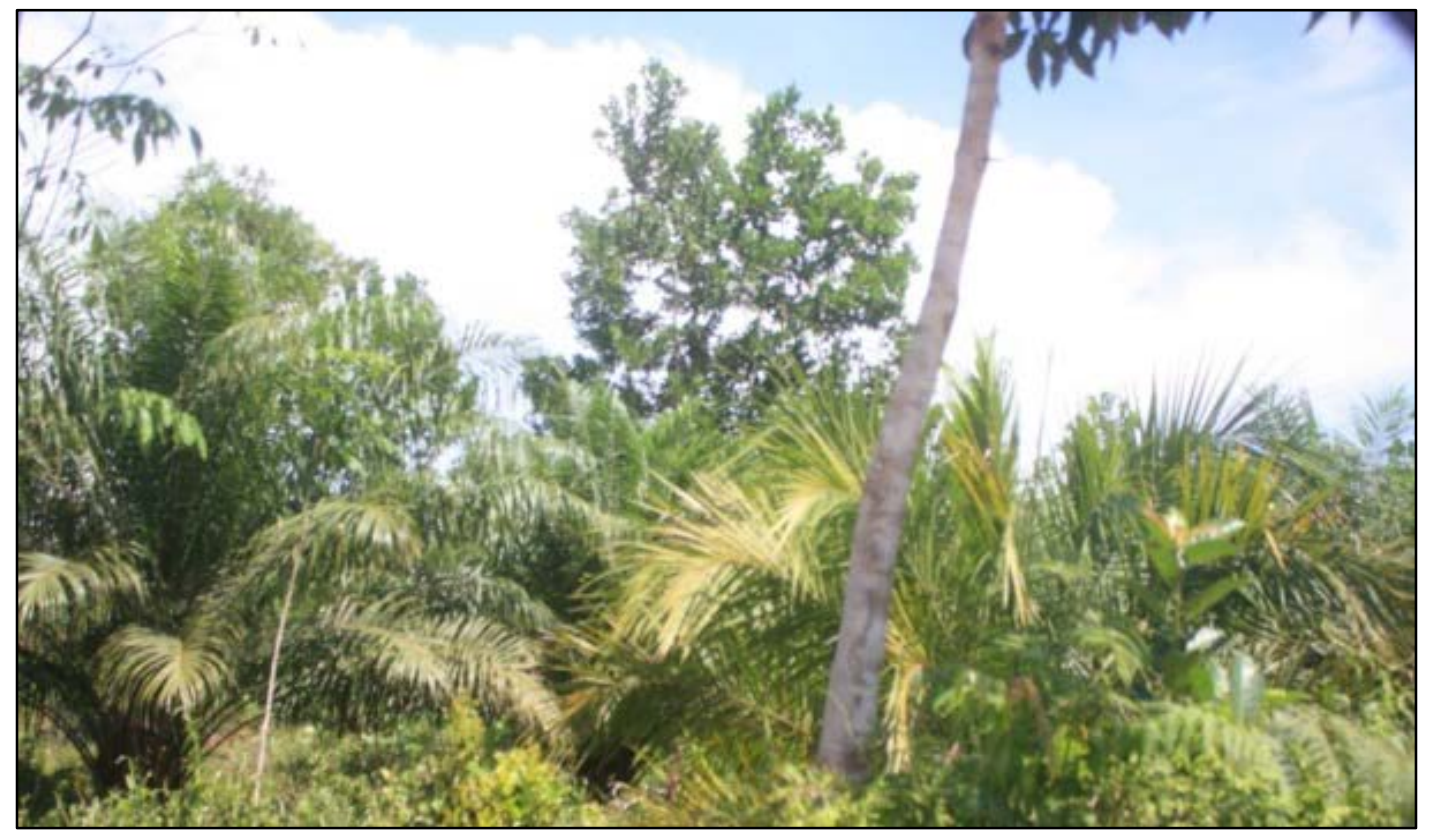

Figure 4: The people's oil palm plantations are around 5-6 years old. Source: Field research, May 2018.

\section{Discussion}

Shifting cultivation is practiced as part of a diversified strategy to fulfill dietary needs and to reinforce claims to land. Alongside this, community plantations help to fulfill household economic needs, also stake a claim to land, and are responsive to the market economy that has penetrated the villages. Diverse livelihood practices are nested within political, ecological, and economic contexts that are challenging. Practically, communication among relevant actors is required, alongside recognition of the village development agenda. At the theoretical level the differing perspectives on the existence of shifting cultivation outlined above need to be bridged. There are four points relevant to this agenda.

First: Synergies between the subsistence strategy of shifting cultivation and community plantations in the face of the market economy.

Conditions in the field show the contrast between a past where land was readily available, and today where land has become a limited resource, with implications for the persistence of shifting cultivation. Extensive cultivation, expanding and clearing new land areas with simple technology and fire (Dove 2015; Geertz 2016), is now impossible given the expansion of company land and some new regulations. Forestry and plantation concession areas are taking over large parts of West Kalimantan (Li et al. 2014; Siahaya et al. 2016). The expansion of large scale company land (Bissonnette and Koninck 2015), prohibitions on burning (Thung 2018), fluctuating commodity prices, and complex socio-economic needs have led to a major decline in shifting cultivation. It is practiced to claim land and to produce food. Labor inputs to agriculture are balanced with paid work at forestry and plantation companies. The transformation in land uses and toward a commercial model has been rapid, and has affected community members and households (Santika et al. 2019).

Community plantations have a strong historical basis in the region, and have been exploited from one generation to the next. Today, they respond to fluctuating commodity prices, with rubber being more established than oil palm as commercial crops. The transformation of subsistence farming is driven by the pressures imposed on it, and by new opportunities for cash income and paid labor, as occurs elsewhere in Indonesia (Santika et al. 2019; Toumbourou and Dressler 2020; Wibowo et al. 2019). Buying rice, corn, 
CGPRT, and vegetables at the market has started to develop in the study villages, using cash earned by labor and commercial sales. Thee socio-cultural values and principles followed by shifting cultivators are pitted against pressures generated by external market forces, presenting present new values, standards and principles, and new ways of managing natural resources and socioeconomic life.

\section{Second: The political ecology of shifting cultivators entering the market economy}

In the perspective of political ecology, the performance of current cultivation practices is inseparable from economic-political issues occurring outside of the villages. Economic-political policies providing freedom for large-scale industrial development become a specter to the community through the land conversion mechanism that dispossesses or denies access to farmers in favor of corporate interests, enabled by the state (Li 2016; Peluso 2005; Wibowo et al. 2019). The compensation approach used by the latter is wrapped in tradition, but still undermines the local land tenure system. The license that companies have is powerful, affecting the social and material relations of extensive agriculture. The licenses that large companies operating at the national level have, cannot be stopped by local level customary institutions. In fact, the involvement of customary and community figures in the land acquisition mechanism weakens the local community's internal decisionmaking mechanisms. For the interests of village development, the land conversion process should support rather than overturn community livelihoods.

The dominant Dayak and also Malays still conduct some shifting cultivation. Although corroboration from more household scale data is still required, it is apparent that a decline in the techno-social management of shifting cultivation is occurring evenly throughout all the kampongs. The culture of subsistence agriculture and hunting is giving way to broader based livelihoods but these are neither stable nor sustainable options. The case of the disbandment of the land acquisition team, which consisted of community and customary figures, without confirmation, the termination of local worker's employment, and lack of access to permanent company jobs, all indicate unfair practices implemented by actors controlling the market economy (Petrenko et al. 2016; Sirai 2009; Vos 2013).

Community-scale plantations of oil palm and rubber, along with the emergence of several other smallscale businesses such as swallow's nests and beekeeping, also engage the market. The political ecology of agrarian change is far from smooth. Community rubber plantations are most rooted in history and are developed on the basis of relatively strong land tenure, which they help to maintain during land acquisition. They are also flexible, and complement shifting cultivation. This model is present among Dayak and Malays, as well as some newcomers. The limiting factor is the fluctuating price of rubber (latex), which is currently in decline.

The community oil palm plantation business is a relatively late arrival on the back of extensive commercial production already underway. Nationally, this form of local concession makes up approximately 1.7 million hectares of the 2.5 million ha. in the forest zone (footnote 11, Wibowo et al. 2019). Locally, most community oil palm fields have just entered the early fruit stage. Large companies that "begged for land" from the villagers through the land acquisition mechanism many years ago have now cultivated oil palm, and community interest began at this time. Lacking resources, community lands were cleared by customary figures and community members as they were able, but in the shadow of their commercial neighbors and still reliant on them for purchasing their harvest. Alternative business exploits, market information, and technical competence is sometimes lacking to anticipate uncertain and fluctuating commodity prices (Abid et al. 2015; Islam and Berkes 2016; Ndamani and Watanabe 2015; Olayemi and Nirmala 2016; Sima et al. 2015).

\section{Third: The need for analytical synergy}

Many studies of shifting cultivation place emphasis on its environmental outcomes and human behavior, alongside the cultural core values of diverse peoples in the Indonesian rainforest. The cultural core element includes organization of livelihoods, the economic system, social organization, and technology at community level (Dove 2015; Geertz 2016; McCullough 2019; Siahaya et al. 2016). ${ }^{12}$ Political ecologists

\footnotetext{
${ }^{12}$ Geertz's research in Indonesia (2016), conducted in the 1960s, developed a theory of agricultural involution, largely referring to sawah rice production systems in heavily populated Java and the Inner Islands. But he also depicts swidden
} 
recognize that agrarian societies are laden with the effects of politics, the expression of power by elites and corporate actors, and injustices (Friedmann 2015; Li 2015; Mathevet et al. 2015; Peluso 2005; Ring 2020; Toumbourou and Dressler 2020; Willow and Wylie 2014; Zanotti et al. 2020; Zimmerer and Bassett 2003). A point of convergence, linking the conceptual interests of cultural and political ecology, is to interrogate how shifting cultivation as a strategy for ecological-economic adaptation operates, but it is constantly affected by national policies, global-national politico-economic interests, rights to natural resources, and issues of global climate change (Ndamani and Watanabe 2015; Sima et al. 2015; Thaler and Anandi 2017; Thung 2018).

Shifting cultivators increasingly need to respond to the socio-politico-economic reality they are entering into, to have sufficient latitude to access the market economy arena more on their terms. Extending the form of analysis in this article can provide the knowledge needed to strengthen their position, given the major changes occurring in land use and land management. I have stressed the three domains: balancing economicpolitical struggle for environmental resources, the cultural meanings attached to the environment, and the changing dynamics of ecology-environment (Benjaminsen and Svarstad 2019; Nygren and Rikoon 2008; Peterson 2000; Quandt 2016).

\section{Fourth: Opening communication among actors and transforming village development}

The management of shifting cultivation as a land-based, village level practice is crucial because land is still the basis of many livelihoods, despite the onset of commercial activities in and around village lands that have led to social and economic problems (Vos 2013). ${ }^{13}$ Formal regulations ${ }^{14}$ now determine the rights of local communities in Indonesia, particularly in the land acquisition process. Formal regulations regarding the land acquisition process that take into account the interests of the community have not been effective in the field. The company adopted the tactic of involving community leaders as members of the land acquisition team to facilitate approaching the community. Applied research is needed to accurately map out the distribution of shifting cultivation areas, ensuring that demographic and land use changes are mapped and monitored (Li et al. 2014). Better communication among actors in relation to village development must emphasize improvements in land management, community plantation management and technology, annual crop variety options, adaptation to changing planting periods, and access to market information so that shifting cultivators/farmers can make calculated adjustments to changes in their environment (Olsson and Jerneck 2010).

\section{Conclusion}

Many smallholder farmer families depend on shifting cultivation in rural West Kalimantan, and they are facing dynamic socioeconomic pressures. The extensive nature of shifting cultivation, in which the aim of increasing production is achieved by expanding and clearing new land areas, is being limited by the expansion of company land and policies that restrict traditional modes of cultivation (Dove 2015; Geertz 2016; McCullough 2019; Siahaya et al. 2016). The expansion of large-scale commercial oil palm conflicts directly with shifting cultivation activities. Economic pressure from outside village communities has pushed for technical adaptation in the management of shifting cultivation, and triggered practitioners to adapt. The adaptation process, on the one hand, is a response to limited land access, while on the other hand, it is a response to policies and rules that inhibit shifting cultivation (Li et al. 2014; Thaler and Anandi 2017; Thung 2018). Shifting cultivation today is not only a subsistence strategy for fulfilling dietary needs, it is also a strategy to maintain land tenure claims.

cultivation as a form of human adaptation that retains many elements of tropical forest landscapes and ecologies under low population pressures in the Outer Islands. The political ecology of land use change in West Kalimantan today makes it difficult to sustain Geertz's depiction of the swidden system and of shifting cultivation.

${ }^{13}$ Emphasis on the need to resolve issues of land tenure for shifting cultivators is in line with the agenda of Agrarian Reform as one of Indonesian Government's current National Priority Programs.

${ }^{14}$ Regulation of the Minister of Environment and Forestry of the Republic of Indonesia: Permen-LHK RI Number: P.12/Menlhk-II/2015 on the Development of Industrial Forest Plantation. 
The rampant conversion of community land into large scale company land with commercial management has influenced the performance of shifting cultivation and driven its practitioners to enter the market economy (Petrenko et al. 2016; Sirai 2009; Vos 2013). Village initiatives to develop community plantations based on industrial commodities in the form of rubber and oil palm are efforts to adapt to these socioeconomic and commercial pressures. Nonetheless, community plantations, be it rubber fields or oil palm, still retain subsistence production, but have uncertain futures since situated on concession areas owned by plantation and forestry companies. Social and economic changes at village level triggered by commercial land ownership and reductions in land availability are not compensated by other livelihood opportunities emerging in the commercial forestry and plantation sectors. The best that unskilled local populations can hope for is daily laborer work.

The theoretical implication of this study is that communication and synergy between different perspectives on agrarian change are required, not least to understand subsistence strategies as the market economy advances into the region. Complex economic and environmental issues can be understood through research that synergizes both cultural ecology and political ecology approaches. Shifting cultivators today are in a situation in which they must enter a market economy that demands certain competencies. Under such conditions, socio-cultural values and principles among shifting cultivator/farmer communities are still necessary. Cultural ecology is useful to document these, since it contextualizes the cultural values and life principles of village communities as agrarian change advances (Dove 2015; Geertz 2016; McCullough 2019; Siahaya et al. 2016). These communities also need to understand the social-economic-political realities they face, and their implications. To strengthen their position, the political ecology of the forces affecting their region can inform them (Li 2015; Peluso 2005; Toumbourou and Dressler 2020). Research, but also the perspectives underlying these two approaches, can help to reestablish an integrated understanding of the links between economic-political struggle for natural resources, the cultural meanings attached to the environment, and the changing dynamics of ecology-environment (Benjaminsen and Svarstad 2019; Nygren and Rikoon 2008; Peterson 2000; Quandt 2016).

The expansion of large scale companies in rural areas, thereby dispossessing local communities, needs to be given serious attention and transformed into a village development approach (Abid et al. 2015; Ndamani and Watanabe 2015; Olayemi and Nirmala 2016; Rahman et al. 2017; Sima et al. 2015). Transformation is important because continued expansion can coopt the community's existence as shifting cultivators and farmers whose livelihoods and worldviews rely on the availability of land. The practical implication of the present study is placing the village community centrally in every land-based village economic development agenda. Alternative partnership schemes between companies and local communities need to provide the community with the freedom to strengthen their own capacity and resilience, to adapt to the dynamics of the market economy.

\section{References}

Abid, M., J. Scheffran, U.A. Schneider and M. Ashfaq. 2015. Farmers' perceptions of and adaptation strategies to climate change and their determinants: the case of Punjab Province, Pakistan. Earth System Dynamics 6: 225-243.

Abu-Lughod, L. 1990. The romance of resistance: tracing transformations of power through Bedouin women. American Ethnologist 7(1): 41-55.

Acciaioli, G.L. and D. Oetami. 2016. Opposition to oil palm plantations in Kalimantan: divergent strategies, convergent outcomes. In R. Cramb and J. McCarthy (eds.). The oil palm complex: smallholders, agribusiness and the state in Indonesia and Malaysia. Singapore: NUS Press. Pp. 327-353.

Almalki, S. 2016. Integrating quantitative and qualitative data in mixed methods research-challenges and benefits. Journal of Education and Learning 5(3): 288-296.

Anonymous. 2017. BPS-Statistic of Ketapang Regency 2017. Ketapang: BPS-Statistic Ketapang Regency.

Archibald, M.M., A.I. Radil, X. Zhang and W.E. Hanson. 2015. Current mixed methods practices in qualitative research: a content analysis of leading journals. International Journal of Qualitative Methods 14(2): 533. 
Barber, M., S. Jackson, J. Dambacher and M. Finn. 2015. The persistence of subsistence: qualitative socialecological modeling of Indigenous aquatic hunting and gathering in tropical Australia. Ecology and Society 20(1).

Benjaminsen, T.A. and H. Svarstad. 2019. Political ecology. In Fath, B. (ed.). Encyclopedia of ecology. Vol. 4. Elsevier. Pp. 391-396.

Bissonnette, J.F. and R.D. Koninck. 2015. Large plantations versus smallholdings in Southeast Asia: historical and contemporary trends. Presented at Land grabbing, conflict and agrarian-environmental transformations: perspectives from East and Southeast Asia. Chiang Mai.

Brown, D. and K. Schreckenberg. 1998. Shifting cultivators as agents of deforestation: assessing the evidence. Natural Resource Perspectives No. 29. London: ODI.

Bullinger, C. and M. Haug. 2012. In and out of the forest: decentralisation and recentralisation of forest governance in East Kalimantan, Indonesia. Austrian Journal of South-East Asian Studies / Österreichische Zeitschrift Für Südostasienwissenschaften 5: 243-262.

Chan, N. and S. Takeda. 2016. The transition away from swidden agriculture and trends in biomass accumulation in fallow forests: case studies in the Southern Chin Hills of Myanmar. Mountain Research and Development 36(3): 320-331.

Choocharoen, C., A. Neef, P. Preechapanya and V. Hoffmann. 2014. Agrosilvopastoral systems in Northern Thailand and Northern Laos: minority peoples' knowledge versus government policy. Land 3(2): 414436.

Connolly, C. 2017. "Bird cages and boiling pots for potential diseases": contested ecologies of urban 'Swiftlet farming' in George Town, Malaysia. Journal of Political Ecology 24: 24-43.

Creswell, J.W. 2013. Quantitative inquiry and research design: choosing among five approaches. Thousand Oaks, CA: Sage.

Dove, M.R. 2015. The view of swidden agriculture, by the early naturalists Linnaeus and Wallace. In M.F. Cairn (ed.). Shifting cultivation and environmental change: indigenous people, agriculture and forest conservation. London: Earthscan. Pp. 3-24.

Dressler, W.H., D. Wilson, J. Clendenning, R. Cramb, R. Keenan, S. Mahanty, T.B. Bruun, O. Mertz and R.D. Lasco. 2017. The impact of swidden decline on livelihoods and ecosystem services in Southeast Asia: a review of the evidence from 1990 to 2015. Ambio 46(3): 291-310.

Elmhirst, R., M. Siscawati, B.S. Basnett and D. Ekowati. 2017. Gender and generation in engagements with oil palm in East Kalimantan, Indonesia: insights from feminist political ecology. The Journal of Peasant Studies. 44(6): 1135-1157.

Friedmann, H. 2015. Governing land and landscapes: political ecology of enclosures and commons. Canadian Food Studies / La Revue Canadienne Des Études Sur l'alimentation 2(2): 23-31.

Geertz, C. 2016[1963]. Involusi Pertanian: proses perubahan ekologi di Indonesia. Jakarta: Komunitas Bambu. In English

Gönner, C. 2007. Surfing on waves of opportunities: resilient livelihood strategies of Dayak Benuaq Forest users in East Kalimantan, Indonesia. Society and Natural Resources 24(2): 165-173.

Islam, D. and F. Berkes. 2016. Can small-scale commercial and subsistence fisheries co-exist? lessons from an indigenous community in Northern Manitoba, Canada. Maritime Studies 15: 1.

Kingwell-Banham, E. and D.Q. Fuller. 2012. Shifting cultivators in South Asia: expansion, marginalisation and specialisation over the long term. Quaternary International 249: 84-95.

Li, P. and Z. Feng. 2016. Extent and area of swidden in montane mainland Southeast Asia: estimation by multi-step thresholds with Landsat-8 OLI data. Remote Sensing 8(1): 1-17.

Li, P., Z. Feng, L. Jiang, C. Liao and J. Zhang. 2014. A review of swidden agriculture in Southeast Asia. Remote Sensing 6 (2): 1654-1683. 
Li, T.M. 2015. Social impacts of oil palm in Indonesia: a gendered perspective from West Kalimantan. Occasional Paper 124. Bogor, Indonesia: CIFOR. https://www.cifor.org/publications/pdf_files/OccPapers/OP-124.pdf

Li, T.M. 2016. Ketergurusan antargenerasi di zona perkebunan kelapa sawit di Indonesia. Jurnal Analisis Sosial |20(1 \& 2): 43-72.

Maharani, C., M. Moeliono, G. Wong, M. Brockhaus, R. Carmenta and M. Kallio. 2019. Development and equity: A gendered inquiry in a swidden landscape. Forest Policy and Economics 101: 120-128.

Maring, P. 2015. Culture of control versus the culture of resistance in the case of control of forest. Makara Human Behavior Studies in Asia 19(1): 27-38.

Mathevet, R., N.L. Peluso, A. Couespel and P. Robbins. 2015. Using historical political ecology to understand the present: water, reeds, and biodiversity in the Camargue Biosphere Reserve, Southern France. Ecology and Society 20(4).

McCarthy, J.F. 2010. Processes of inclusion and adverse incorporation: oil palm and agrarian change in Sumatra, Indonesia. The Journal of Peasant Studies 37(4): 821-850.

McCullough, C. 2019. Review of 'Agricultural involution: the processes of ecological change in Indonesia' by Clifford Geertz. International Journal of Anthropology and Ethnology 3(1).

Meilasari-Sugiana, A. 2018. Oil palm companies, privatization and social dissonance: towards a socially viable and ecologically sustainable land reform in Tanah Laut Regency, South Kalimantan, Indonesia. Journal of Political Ecology 27: 548-468.

Mertz, O. and T.B. Bruun. 2017. Shifting cultivation policies in Southeast Asia: a need to work with rather than against, smallholder farmers. In M. Cairns (ed.). Shifting cultivation policies: balancing environmental and social sustainability. Wallingford: CABI. Pp. 27-42.

Minardi, A. and P.I. Maulani. 2019. Implementation of Indonesia's foreign investment policy in the development of Japan foreign direct investment in Indonesia. Presented at ICASI 2019, July 18-19, Banda Aceh, Indonesia. https:/eudl.eu/pdf/10.4108/eai.18-7-2019.2288642.

Nassaji, H. 2015. Qualitative and descriptive research: data type versus data analysis. Language Teaching Research 19 (2): 129-132.

Ndamani, F. and T. Watanabe. 2015. Farmers' perceptions about adaptation practices to climate change and barriers to adaptation: a micro-level study in Ghana. Water 7(9): 4593-4604.

Newby, J., R. Cramb and S. Sakanphet. 2014. Forest transitions and rural livelihoods: multiple pathways of smallholder teak expansion in Northern Laos. Land 3(2): 482-503.

Nugraha, A. and Tim. 2018. Hasil identifikasi dan pengelolaan masyarakat di dalam dan sekitar konsesi perusahaan di Kabupaten Ketapang, Kalimantan Barat. Jakarta: Wana Aksara Institute.

Nygren, A. and S. Rikoon. 2008. Political ecology revisited: integration of politics and ecology does matter. Society and Natural Resources 21(9): 767-782.

Olayemi, B. and D. Nirmala. 2016. Creating economic viability in rural South Africa through water resource management in subsistence farming. Environmental Economics 7(4): 68-77.

Olsson, L. and A. Jerneck. 2010. Farmers fighting climate change-from victims to agents in subsistence livelihoods. Wiley Interdisciplinary Reviews: Climate Change 1 (3): 363-373.

Palupi, S., Y.S. Sukapti, S. Maemunah, P. Prasetyohadi and A. Tømte. 2017. Privatisasi transmigrasi dan kemitraan plama menopang industri sawit: resiko hak asasi manusia dalam kebijakan transmigrasi dan kemitraan plasma di sektor industri perkebunan sawit. Jakarta: The Institute for Ecosoc Rights and Norwegian Center for Human Rights (NCHR).

Peluso, N.L. 2005. Seeing property in land use: local territorializations in West Kalimantan, Indonesia. Geografisk Tidsskrift, Danish Journal of Geography 105(1): 1-15.

Peluso, N.L. 1992. Rich forests, poor people: resource control and resistance in Java. Berkeley and Los Angeles: University of California Press. 
Penot, E. 2007. From shifting cultivation to sustainable jungle rubber: a history of innovations in Indonesia. In M. Cairns (ed.). Voices from the forest: integrating indigenous knowledge into sustainable upland farming. Washington : RFF Press. Pp. 577-599.

Peterson, G. 2000. Political ecology and ecological resilience: an integration of human and ecological dynamics. Ecological Economics 35: 323-336.

Petrenko, C., J. Paltseva and S. Searle. 2016. Ecological impacts of palm oil expansion in Indonesia. White Paper. Washington DC: International Council on Clean Transportation. https://theicct.org/sites/default/files/publications/Indonesia-palm-oil-expansion_ICCT_july2016.pdf.

Quandt, A. 2016. Towards integrating political ecology into resilience-based resource management. Resources 5(4): 31.

Rahman, S.A., J.B. Jacobsen, J.R. Healey, J.M. Roshetko and T. Sunderland. 2017. Finding alternatives to swidden agriculture: does agroforestry improve livelihood options and reduce pressure on existing forest? Agroforestry Systems 91(1): 185-199.

Ribolzi, O., O. Evrard, S. Huon, A.D. Rouw, N. Silvera, K.O. Latsachack, B. Soulileuth, R. Lefèvre, A. Pierret, G. Lacombe, O. Sengtaheuanghoung and C. Valentin. 2017. From shifting cultivation to teak plantation: effect on overland flow and sediment yield in a montane tropical catchment. Scientific Reports 7(1).

Ring, M.S. 2020. SandLife and the death of dunes: political ecology discourses from conservation to restoration in Haverdal, Sweden. Journal of Political Ecology 27: 67-83.

Rösler, M. 1997. Shifting cultivation in the Ituri Forest [Haut-Zaïre]. Civilisations 44: 44-61.

Santika, T., K.A. Wilson, E. Meijaard, S. Budiharta, E.E. Law, M. Sabri, M. Struebig, M. Ancrenaz and T.M. Poh. 2019. Changing landscapes, livelihoods and village welfare in the context of oil palm development. Land Use Policy 87: 104073

Saqib, E.S., J.K.M. Kuwornu, S. Panezia and U. Ali. 2018. Factors determining subsistence farmers' access to agricultural credit in flood-prone areas of Pakistan. Kasetsart Journal of Social Sciences 39(2): 262-268.

Scott, J.C. 1976. The moral economy of the peasant: subsistence and rebellion in Southeast Asia. New Haven: Yale University Press.

Scott, J.C. 1985. Weapon of the weak: everyday forms of peasant resistance. New Haven: Yale University Press.

Scott, J.C. 1992. Domination and the arts of resistance: hidden transcripts. New Haven: Yale University Press.

Setyowati, A.B. 2020. Governing the ungovernable: contesting and reworking REDD+ in Indonesia. Journal of Political Ecology. 27: 456-475.

Siahaya, M.E., T.R. Hutauruk, H.S.E.S. Aponno, J.W. Hatulesila, and A.B. Mardhanie. 2016. Traditional ecological knowledge on shifting cultivation and forest management in East Borneo, Indonesia. International Journal of Biodiversity Science, Ecosystem Services and Management 12(1-2): 14-23.

Sima, M., E.A. Popovici, D. Bălteanu, D.M. Micu, G. Kucsicsa, C. Dragotă and I. Grigorescu. 2015. A farmerbased analysis of climate change adaptation options of agriculture in the Bărăgan Plain, Romania. Earth Perspectives 2(5).

Sirait, M. 2009. Indigenous peoples and oil palm plantation expansion in West Kalimantan, Indonesia. Working Papers b16385. Nairobi: World Agroforestry Centre. http://apps.worldagroforestry.org/downloads/Publications/PDFS/RP16385.pdf

Srivastava, A. and S.B. Thomson. 2009. Framework analysis: research note. Journal of Administration and Governance 4(2): 72-79.

Sulistyawati, E., I.R. Noble and M.L. Roderick. 2005. A simulation model to study land use strategies in swidden agriculture systems. Agricultural Systems 85(3): 271-288.

Terauchi, D., N. Imang, M. Nanang, M. Kawai, M.A. Sardjono, F. Pambudhi and M. Inoue. 2014. Implication for designing a REDD+ program in a frontier of oil palm plantation development: evidence in East Kalimantan, Indonesia. Open Journal of Forestry 4(3): 259-277. 
Thaler, G.M. and C.A.M. Anandi. 2017. Shifting cultivation, contentious land change and forest governance: the politics of swidden in East Kalimantan. The Journal of Peasant Studies 44(5): 1066-1087.

Thung, P. H. 2018. A case study on the persistence of swidden agriculture in the context of post-2015 antihaze regulation in West-Kalimantan. Human Ecology 46: 197-205.

Toumbourou, T.D. and W.H. Dressler. 2020. Sustaining livelihoods in a palm oil enclave: differentiated gendered responses in East Kalimantan, Indonesia. Asia Pacific Viewpoint https://doi.org/10.1111/apv.12265

Vayda, A.P. 1983. Progressive contextualization: methods for research in human ecology. Human Ecology 11: 265-281.

Vos, E.D. 2013. Palm oil land disputes in West Kalimantan: the politics of scale in processes of dispute resolution. An empirical research on dispute resolution strategies in Sambas District. MSc thesis. Wageningen University and Research Center.

Wibowo, L.R., I. Hakim, H. Komarudin, D.R. Kurniasari, D. Wicaksono and B. Okarda. 2019. Penyelesaian tenurial perkebunan kelapa sawit di kawasan hutan untuk kepastian investasi dan keadilan. Bogor: CIFOR. https://www.cifor.org/publications/pdf files/WPapers/WP247Wibowo.pdf.

Willow, A.J. and S. Wylie. 2014. Politics, ecology, and the new anthropology of energy: exploring the emerging frontiers of hydraulic fracking. Journal of Political Ecology 21 (1): 222-236.

Zanotti, L., C. Carothers, C.A. Apok, S. Huang, J. Coleman and C. Ambrozek. 2020. Political ecology and decolonial research: co-production with the Iñupiat in Utqiagivik. Journal of Political Ecology 27: 4366.

Zimmerer, K.S. and T.J. Bassett. 2003. Approaching political ecology: society, nature, and scale in humanenvironment studies. In K.S. Zimmerer and T.J. Bassett (eds.). Political ecology: an integrative approach to geography and environment - development studies. New York: Guilford Press. Pp. 1-25. 